\title{
Revitalizing secondary market Brownfield sites
}

\author{
A. Bogen \\ President, Down to Earth Consulting, Environmental Planner Regional \\ Brownfields Partnership of West Central Connecticut, USA
}

\begin{abstract}
Brownfield sites in secondary markets will only be revitalized through public investment. The market place has passed on these sites or never considered them in the first place because they carry multiple burdens. They are in secondary markets where land values and demographics are not strong. They can also be too small, suspected of being too contaminated, have dilapidated structures and owe too much in back taxes. These are conditions that will not be resolved without significant long term public intervention and investment. The criteria for this investment needs to be applied along with the commitment of the marketplace to rebuild the sites if they are within certain economic parameters after assessment. This is a discussion of how certain criteria are being applied in an industrial city in the USA.
\end{abstract}

Keywords: public investment, delinquent taxes, access, value, liability.

\section{Introduction}

There are Brownfield sites that the marketplace has already passed on that will only be restored with public financing. The burdens they carry will require significant public investment. Public leadership will need to accept and advocate nontraditional returns on that investment. The payback is in decades rather than in 15 to 20 years. For these dark sites, there is only the option of public investment to leverage them into reuse. Left alone, these sites will be a continuous cause of disinvestment, degrading the neighborhoods and negatively affecting the people who live near them. This paper lays out some of the measurements that can be used to justify the tremendous investment that is required. 
It may be useful to illustrate the conditions of these sites through a case history that is unfolding in an older industrial city, Waterbury, Connecticut formerly known as the Brass City. There are difficult issues holding back the reuse of the many city Brownfields. Major industrial players on the world stage had facilities located here. Today those former titans are represented by fading painted signs and their Brownfields legacy of rusting, imploding hulks of highly specialized manufacturing facilities sitting empty. The assumption is that these sites are significantly contaminated. There is repeated documentation from environmental assessments on similar sites of the presence of polyaromatic hydrocarbons, heavy metals, ash and sludge. There are filled areas along the Naugatuck River where the ash residues are more than ten feet deep.

Waterbury, a city with a population of 107,000 people in 2000 , needs to generate more taxes from this tired real estate infrastructure pervasive within its limited borders. Therefore, the first reason to invest in these sites is to allow them to return to tax generation. The burden of delinquent taxes is significant in the older industrial, secondary market cities, such as Waterbury. The city, faced with troubled tax collection rates, about 15 years ago, attempted to sell liens on some of the biggest tax debts. The lien holders want full payment. The result is that the steep old tax bill alone is often enough to discourage an investor because the properties are much inverted in value. Some of these old tax debts are carried forward as part of the analysis to balance a budget even though the likelihood of collection is open to challenge.

\section{A case in point}

In Waterbury, one site has been offered at tax auction 8 times without a bidder. The back tax bill on this two acre parcel is $\$ 832,000$ US. If it was a clean site, it might be worth $\$ 200,000$. There is a dilapidated structure that once housed a dry cleaning plant and retail outlet. Bidders have not come forward because of the unknown environmental conditions. The site is within a healthy, growing retail corridor including a revived mall and is accessible to several suburban communities as well as to the downtown. The Brownfields project has undertaken a Phase I and II assessment with an estimated cost of cleanup required in the Scope of Work. Once the assessment is complete, the site will again be offered at auction. Said assessment will cost about $\$ 20,000$.

There was some debate as to whether this site should receive grant assessment funding. It is not the most blighted site within the city. Other sites owe more taxes. The building sits on a rise so the structure and the random trash piles do not have immediate street impact as this condition does on other sites. However, there have been inquiries to the City about the availability of the site. Without specific information about the environmental conditions, it will never sell at auction. The State records do not indicate any release of TCE, tetrachloroethylene, so it is possible that the cleanup could be minimal. The decision to assess this site was made as much on the basis of intervention as on any other category. Because the site is relatively small, the assessment cost is 
small in relation to the uncollected taxes. Turning it around can help to forestall any area decay and promote economic development.

The site also illustrates another key component of the causes of Brownfields. The owners have abandoned the site and it is owned by a corporation that has not been responsive to tax notices. Certified letters were sent to the listed person of notice. He responded that he had nothing to do with the management of the property and provided another name. That person subsequently responded that he would provide data from previous tests and would sign the access agreement. Several weeks went by without the executed access agreement being returned and follow up phone calls were not returned. Mention was made of the voice mail the owner had left, agreeing to provide access. More than five months from the first conversation and nearly nine months after the decision to assess the site, the access was granted. The earlier reports promised by the owner have not been received. Perseverance and an assertive management posture are required by the team working to overcome obstacles such as these. There has to be a willingness to take legal action to gain access to such sites. This outcome was fortunate and came about more by chance and diligence than policy or specific device.

\section{The City today}

The City is owed millions of uncollectible dollars on sites located all over the City. Almost no neighborhood is immune from the effect; the number of sites is stunning. Many small parcels had secondary businesses that provided services and materials and goods for the mills and factories. The tool and die makers and metal platers are largely gone but their contaminants remain. For more than 40 years there has been a diminution of the tax base making it very difficult to govern under such a burden. A major shopping mall has been built on one of the largest former industrial sites. Some of the stores in the mall are doing acceptable sales volumes but the anchor supermarket just closed leaving the core city without any such facility. The State invested monies into constructing a branch of the University of Connecticut in the downtown Central Business District. The facility replaced aging and largely vacant downtown retail buildings. The State also built a courthouse, renovated a large splendid theater across the street from the University branch and built an arts magnet school. These infusions have had some effect. The students at both the magnet school and the UCONN branch represent a positive new element to the downtown area. Several people have commented on the new faces downtown and the increased traffic on feeder routes. However, these students are commuters and for now, not spending a lot of money in the City as was anticipated prior to construction.

The historic City has also suffered the indignity and disruption of an Interstate highway slicing through its heart, uprooting the traditional patterns of commerce. The feeder roads have numerous pinch points, parking on the narrow streets is inconvenient and uncoordinated traffic signals all impede traffic flow. It is very frustrating to try to get from one area of the city to another. The contemporary commercial development is sporadic, mainly huddled together in widely distributed pockets among blocks of blighted structures. 
In the past, downtown was home to numerous stores that provided services and sold fine goods to the emerging middle class, factory workers and residents of nearby communities. The factories adjacent to the downtown had three shifts of workers who were making living wages and patronizing these stores. Workers lived downtown as well as in other areas of the city. Public transportation had its major hub in the downtown, reaching out to all points of the City. Waterbury today is plagued by a high commercial vacancy rate. After the closing of the many factories and their ancillary suppliers and operations, the unemployment rate has soared, in contrast to the fact that Connecticut has the highest per capita income in the United States. Waterbury has one of the highest unemployment and poverty rates in the State.

The urban core has difficult demographics, due to it being the home to the highest density of poor residents. There is hardly a block without an abandoned building. The infrastructure is tired and in disrepair. There is gang and drug activity. The city has also been plagued by a series of corrupt and dishonored mayors. The current administration has now been reelected twice and has a reputation for integrity. The City was bankrupt and administered by the state for a number of years, emerging from that control last year. Difficult union pension obligations were contested and resolved.

Economic development efforts continue to be thwarted by the lack of virgin land and Brownfield sites ready for reuse, although there are developer inquiries made to the responsible agencies with mixed results. The shelves are bare - the Brownfields have not been prepared for reuse. Against this problematic background, the City is moving forward in its efforts to revitalize its Brownfields. Public money is providing the support.

\subsection{The process and concerns}

The first step taken in identifying and assessing sites was to establish a process for site selection. From the onset, it was important that a set of criteria for selection be established. The Mayor, City department heads, business and community leaders and the funding authority were involved. Sites would have to have certain attributes to be selected for assessment grants. Several of the criteria were first tier and were determined to be required in the application for a site to be assessed. These were proof of a proposed transaction, access, a beneficiary that did not cause the suspected or known contamination and a reuse that fit the City's Plan of Conservation and Development. Additional criteria were delinquent taxes, with concern for third party lien sites, community comment and regulatory review. When the consultant has developed the information on the site, a form is filled out that elaborated on data related to these criteria. Preliminary approval is sought from the State program managers. Next the Site Selection Committee reviews the proposal. Committee members are drawn from a wide community base. Their deliberation helps to assure that the public benefit is real and that the process is transparent.

There is often a lot of emotion surrounding the present site conditions. The general public is angry that the blighted and unknown and potentially dangerous conditions have been allowed to fester for so long, in some cases for half a 
century. They are frustrated and appalled by the corporate veil that can insulate the owners from effective enforcement action. The need to blame is met with what are seen to be a wall of rationalizations. The questions are poignant. Some individuals think the health agencies should have acted, the owners been prosecuted and that the government should have managed the problem. They feel that there should have been enforcement of regulation long before the sites were contaminated and abandoned. Issues of access and corporate insulation are further insults and obstacles to what is perceived of as a morally right resolution. For some the equation is simple - the sites are dirty; clean them up.

The site owners have their separate batch of concerns. They are wary of granting access because they often don't want to know what is on the site. They are concerned that the information could cause enforcement action, resulting in astronomical remediation costs, which could bankrupt them. Some sites are still held in personal partnerships or entities with individual exposure. The assets of those individuals and families could be built on a house of cards foundation. Prior to the establishment of remedial regulations that help to define what has to be done on a site, the regulator could act individually and arbitrarily in the eyes of the business community. Stories remain about environmental remediation without end. There was no certainty and great risk. Even if the intention was to try to do something beneficial and to make corrections, the cooperative and assertive position could be financially imprudent. That basic fear of economic ruin remains as does the very real exposure.

Waterbury has ongoing concerns about being proactive on sites. It too does not want to invoke liability exposures by discovering issues that it then must address. It could have additional liability if its agents are hurt on a site or cause damage. The risk is deemed too great to act without the listed owner granting access. There are statutes that the City will wait for others to use with the resultant established case law. Some other communities also facing significant Brownfield sites have gone to court to gain access.

\subsection{Creating an entity to hold the liability}

Going forward, the issue of access must be addressed in a more proactive way. Regulations allow the government to go on the site if there is a suspected significant health risk, or a release of pollutants to the State waterways. Another criterion, some benchmark of back taxes, should allow access. At a certain point the inverted value just keeps compounding beyond the capacity of any transaction to overturn while buildings and infrastructure continue to deteriorate. Municipalities must be more proactive in managing the assets that comprise their tax base. The political consequence of leaving the sites alone is worse than doing something about it.

It may be that the State needs to act as a neutral temporary repository of liability while the sites are assessed and readied for reuse. Criteria would have to be established taking into account specific factors: back taxes, health risk, and developer interest, compatibility with zoning for the proposed reuse, projected returns and quality of supporting public infrastructure. Municipalities would 
have to apply for the assistance based on completing an application with the site data fitting into a predetermined ranking grid. If accepted, the sites would be placed in a holding entity. The State would assess the site and define the cleanup acceptable under its regulations. There would have to be some federal signoff of the proposed remediation so that the full range of security for finance institutions would be in place. At the point that the cleanup cost is defined, a decision could be made as to whether the site is marketable. With the application of tax abatement and other assistance, the developers may be able to fund the cleanup. Other sites may require cleanup by the State.

Additional criteria could also be considered. Access to public transportation, inclusion of sustainable design components, and renewable energy capacity in the proposed reuse are some criteria to consider. It is not enough any longer to place a big box retailer on a site. It is more than a vision of tomorrow that we need to fulfill. It needs to be a requirement to build in a sustainable fashion. Fuel cells and gray water management would help the urban environment. Public money in the form of tax incentives could be in place to foster these changes. It would be attention getting to have the most blighted places become hallmarks of environmental responsibility. Brownfields represent an opportunity to incorporate on site generation where the grid is readily accessible.

Some of the parcels are too small for a viable reuse. This small size limits the return that the site can generate, making it difficult or impossible to reuse the site. Therefore, another aspect of the criteria for sites to be considered is the possibility of taking enough contiguous parcels to have a market worthy site. Perhaps a City would need to negotiate the options on the sites before presenting them to the State for review. The presence or absence of an option would be weighted in the ranking system.

There can be a lot of reasons to argue against putting the government, whether state or municipal, into an entrepreneurial role. Government is not charged with the creation of wealth. Government employees are asked to function more as processors than innovators. They can and do respond to the need for change and modification of regulations and shifting of paradigms. The taking of these Brownfields properties is a function. The administration of the assessment and cleanup are functions that the State already performs. This is a step that allows these otherwise unusable sites to be made ready for the entrepreneurs' vision and resources. Selection of the reuse plan needs to be an open and bid process so that there is community support for the final decision. Some planning and determination of acceptable reuse should go into the earliest stages of selecting which sites will be assessed. It may be that there needs to be a request for proposals on a short list of these sites to help determine which sites should receive priority. The marketplace will then have said which sites it deems valuable rather than sites selected by members of the community or professional planners.

The sites taken would have to have a proposed reuse with a demonstrable public benefit. It would be important to clarify what constitutes public benefit. Some sites will generate taxes, an obvious public benefit. Some will generate jobs in neighborhoods that desperately need them. Some will abate health risks 
that help not only those in the immediate area but reduce the human health exposures that can put subsequent burden on the health care system. Some sites could be used for recreation or open space, which can provide an amenity that enhances value. Cleaned sites could produce increased taxes through a rise in appraised values of adjacent parcels. Green spaces in urban areas can also reduce the heat island effects, be sites for distributed storm water infiltration and food growing plots. The decision about what is the greatest value can be local in the first place and be arrived at through extended dialogue when sites are first being selected.

\section{Another case in point}

In some instances the marketplace has tried to make a site work but cannot bridge the gap caused by environmental expense. In Waterbury an assessment was done on a similar site. A number of set criteria were met including proof of options held or of ownership on 18 contiguous parcels. There was a potential tenant represented by a realtor to protect their confidentiality. None of the investors had caused the site contamination and there was information on two sites in the State files indicating contamination. The back taxes were minimal and paid up before there was an agreement to fund the assessment.

The results of the assessment established a range of cleanup cost for the 18 contiguous parcels at nearly $\$ 870,000$ US. One parcel alone was estimated at $\$ 500,000$ and another at $\$ 240,000$. The cleanup, plus the acquisition cost and demolition costs made the base cost of the land, if prepared for new construction, too high too build for the prospective tenant. The site has languished for nearly a year since the assessment. Recently the spokesman for the developer has announced that they are trying to complete plans for two mid-rise apartment buildings on a section of the site, which would give them the returns necessary with the density these market rate units would have. The issue under discussion is how to fund the $\$ 240,000$ clean up of one site, which was not caused by the current owner of the factory on that parcel. The current owner is liable and wants to come out whole in any transaction. The question that sits on the table is one of undue enrichment. That is the need to be certain that an individual company does not receive extreme and unjust benefit from pubic funds used for cleanup. The seller has the liability and obligation, which the purchaser could pick up, if that is their deal.

Without intervention the deal may not work. The parcels are in back of the previously referred to Mall. The traffic count for the area is high, and the site is at one end of a blighted stretch that leads downtown to the new University building. A revitalized site could be a bookend for further redevelopment on this main City artery. These conditions spoke in favor of doing the assessment in the first place. These qualities haven't changed. The negative news regarding the cleanup costs has stalled the process. If there is to be change, some leverage has to be provided. In the context of the transaction, the cash is fungible. The assistance does not have to go directly to one party. Funding could be provided 
for demolition, relocation, streetscape requirements or utility upgrades. The public officials will be asked to decide if the revitalization is a worthy outcome. If the City and State do not want to provide some support, this site, with and despite its relative advantages, will pickle in the contamination.

The delays that the owners have experienced in the site process described above have left them without income and frustrated by the lack of resolution. If they weren't primarily local people who own some of the parcels and would not be able to readily sell them, they would have walked away. It does not serve the market to be in sequential crisis when dealing with Brownfield sites. The whole site must be readied for reuse. The obstacles must be defined and resolved. Timing is critical; the process must flow and the resources must be at hand. It is fatal to a deal to wait for the several months to conduct and distill the results of an assessment to find that the cleanup cost has no ready funding options. Low cost loans are of marginal value when the return from these secondary sites is as thin as it has proven to be. If we do not invest in these sites, we must accept the economic and social consequences. The contamination and liability, and therefore the risk, do not go away. These are cash flow situations. The deals don't work without intervention. We have not intervened. The sites remain unleavened.

We need to have the sites ready to be marketed rather than sit and wait for the marketplace to come around and in the end go elsewhere seeking less difficult development options. Failure to act engenders further despair and faithless views of municipal government on the part of the poor and immigrant population that live among many of Waterbury's Brownfield sites as well as in other older industrial cities across the nation. The lack of opportunity is one of the causes of crime and drug use. Reinvestment provides jobs and improves the quality of life and gives people a stake in their communities. Being proactive in the real estate redevelopment may offset the use of some of the public funds for police and counseling expenses. There is no escape from the deteriorated conditions. They will not self improve. The heart of their malaise is economic. Only government can create the leverage to breed jobs and taxes.

In the short term the investment required has limited return. The payback window will not occur in the usual financial parameters. It is possible that the capital invested in structures will have to be renovated before enough taxes have been generated to pay back the investment. That means that the horizon for returns has to be extended past usual meaningful life analysis. Even a thirty year mortgage table could be understating the time needed. However, the critical capital investment isn't in the infrastructure. It is in the land. The land has no useful life restrictions. Once cleaned, with proper operational safeguards and consistent government regulatory enforcement, the land is a renewable resource. Seen this way, the investment provides a revitalized foundation for a continuing tax base. The health risks are abated so the undocumented costs associated with contamination related illness are minimized. The willingness of investors to build on nearby parcels increases the overall tax base and may create new jobs. The effect of rescuing one site can cause positive ripples in an area. 


\section{The journey into tomorrow}

No society has enough resources to clean every Brownfields site in a short term approach. That is why the process of how sites are selected for assessment is such an important part of the process. In order for Brownfields redevelopment to be successful, there has to be some short term returns on investment to the community. Two of the most acknowledged returns are jobs and taxes. In Connecticut, taxes can include property, equipment, sales and income varieties. The conflicting point can be raised about the need for tax abatement to lure investors. This approach has often been used in lieu of providing clean sites. If the developer will clean the site, then the market can handle that site and it is not of the variety that is being discussed here. These sites have extraordinary inversion ratios. We can't count the long term generation of a tax stream while simultaneously offering abatements. The public's capital must be reconstituted. The eligibility of sites will depend on the private reinvestment being adequate for the balance of the turnaround. The sites will be pulled out from the pit to be like other sites but with an early commitment to reuse. Many of these sites have great locations.

These sites also have available infrastructure. The public does not have to invest in new roads, sewers, sidewalks, water supply and other services as when it takes undeveloped land. If those avoided expenses are tallied, the return analysis for these blighted sites improves.

Considered this way, the issue of public investment can be seen as necessary rather than optional. The effect of continued unsustainable development is a destroyed environment. The issue of returns placed in the context of development that supports the ability to live on the planet makes moot a refined and strict analysis of the return on investment. Can there be a better place to demonstrate the functions of new technologies and planned environment than in places so difficult that commerce and government have turned away from wanting to see them? These are the places where we can and need to demonstrate our collective will toward sustainable and healthy design. The investment goes far beyond cleaning up old industrial residues. The dark places can hold the light. The rough places can be made fine. The secondary markets need to be the primary markets for public investment. The land is available. It can be made ready. It must be made ready. 